\title{
Deconstructing Belonging in Lifestyle Migration: Tracking the Emotional Negotiations of the British in Rural France
}

\begin{abstract}
This article examines the emotional negotiations that mark the lived experience of Britons residing in rural France-a paradigmatic case of lifestyle migration-to develop a nuanced understanding of how the lifestyle migrant subject is (re)constructed through migration and settlement. In contrast to presentations of these migrations-both by scholars and migrants themselves-as a freely-chosen self-realization project, the lens on emotion and affect brings into sharp relief the ambivalence experienced by many of these migrants despite their apparent privilege. It highlights the vaue of moving beyond narratives of migration into lived experience; it stresses the importance of recognising that even for the middle classes belonging is a project-in-progress rather than fait accompli; it promotes the idea of lifestyle migrants as translocal subjects, belonging further complicated by ongoing attachments to people and places elsewhere. Through these foci, the article brings together research on lifestyle migration with that on the middle classes and belonging.
\end{abstract}

\section{Key Words}

Lifestyle migration, emotion, migrant subjectivities, privileged migration, belonging 


\section{Introduction}

This article examines the emotional negotiations that mark the lived experience of Britons residing in rural France-a paradigmatic case of lifestyle migration-to develop a nuanced understanding of how the lifestyle migrant subject is (re)constructed through migration and settlement. In contrast to presentations of these migrations-both by scholars and migrants themselves-as a freely-chosen self-realization project, the lens on emotion and affect brings into sharp relief the ambivalence experienced by many of these migrants despite their apparent privilege.

Through this focus, the article brings together research on lifestyle migration with that on the middle classes and belonging. It highlights the vaue of moving beyond narratives of migration into lived experience; it stresses the importance of recognising that even for the middle classes belonging is a project-in-progress rather than fait accompli; it promotes the idea of lifestyle migrants as translocal subjects, belonging further complicated by ongoing attachments to people and places elsewhere. In these ways, the article seeks to contribute to these bodies of research, bringing them into conversation with one another, to present a nuanced understanding of how lifestyle migrant subjectivities are constructed and produced, highlighting the translocal dimensions of these, how they are caught up with social and emotional investments in both the destination and the sites of life before migration.

The article takes a narrative structure intended to showcase these different contributions. It begins with a discussion of my research on lifestyle migration and specifically the British residents of the Lot, outlining the research methodology and reflecting on the relationship with interlocutors. This is followed by a review of lifestyle migration, leading to a section that locates the current research on lifestye migrant subjectivities within debates on belonging and the middle classes. The 
Accepted for publication in the European Journal of Cultural Studies, forthcoming special issue on Mobile Elites - September 2015

article then turns toward the empirical research, first documenting narratives of migration as residential choice before exploring emotions and what these reveal about belonging.

\section{Setting the Scene}

Along with other researchers who have found the concept of lifestyle migration useful for making sense of the privileged migration that they study, I adopted a ethnographic approach to my research which set out to understand British migration to rural France, their experiences of everyday life and settlement. I mention this here as a reminder that the decision to conceptualize this migration trend as lifestyle migration emerged inductively (see also Benson and O'Reilly forthcoming), a reflection of the persistence with which the pursuit of lifestyle lay at the root of my interlocutors' accounts of their migration and their framing of their daily lives. The paper presents a series of ethnographic narratives, in this way laying bare the process of subjectivity-making and how this is marked by emotion. These narratives are about individual interlocutors, while reflecting wider themes within the project.

My research focused on British residents of the Lot, a rural, inland department in the southwest of France. Over a period of twelve months between 2003 and 2005, I lived with a British family, conducting ethnographic research comprised of daily participant observation with the family and with other British residents of the Lotsome of whom I'met through the family, but others who I recruited independentlydocumented through extensive fieldnotes, complementing this with semi- and unstructured interviewing and the collection of life and migration histories.

My interlocutors were diverse in terms of their age and family circumstances at the time of migration; while there was a significant population of retirees, they also included younger (working age) couples and families who had migrated with young children. At the time of the research all were permanent residents in France, living there year round. While some had started small income generating businesses to 
Accepted for publication in the European Journal of Cultural Studies, forthcoming special issue on Mobile Elites - September 2015

support their lives in the Lot, none of my interlocutors had moved to France with the promise of a job. All had relocated to the Lot in the last 20 years, with at least one arriving only six months prior to the start of my research.

In terms of their position within the British social structure, they predominantly originated in the middle classes-many of them had worked in the public sector as teachers or civil servants, while others had been in professional-managerial positions and had educational qualifications corresponding to these positions, even if it was also clear that some of these had experienced considerable social mobility in their lifetimes. Against this background, lifestyle migration was made possible because of my respondents' possession of correspondingly high levels of cultural and symbolic capital.

This paper focuses in particular on the feelings that were expressed within the context of the ethnographic research, focussing on the performative dimensions of emotion, what Svašek $(2008,2010)$ identifies emotion as practice, alongside the recognition of the embodied dimensions of these, tangible in the research encounter (see also Gray 2008). These emotions were the product of the research relationship, emerging not in initial encounters, but further down the line when relationships were firmly established, trust and rapport built up. These were 'experiences of emotion as they are articulated, embodied, practiced, imagined and shared between "subject" and "researcher"' (Baldassar 2008: 251; see also Gray 2008). As the ethnography presented below demonstrates, the most heightened emotions, particularly sadness, loneliness and disappointment, were expressed by female interlocutors; produced through the research encounter, these are telling of the relationship between me as the researcher and these women: I experienced these encounters as emotional. The emotion with which experiences were conveyed was undoubtedly influenced by my own positionality in the field, as a young, white British, middle-class researcher, and reflexively managed throughout the research. What I present below is my interpretation of these emotions as performed in the ethnographic encounter (Gray 2008; Walsh 2012). Identifying emotion as elicited by 
Accepted for publication in the European Journal of Cultural Studies, forthcoming special issue on Mobile Elites - September 2015

the act of migration and as present in everyday life reveals the emotional and social negotiations that mark the daily lives of these lifestyle migrants.

\section{British Migration to Rural France as Lifestyle Migrants}

The migration of the British to rural France is symptomatic of an individual lifestyle choice, part of the wider trend of lifestyle migration ... migration is just one point on the journey towards a better way of life, an intrinsic aspect of the lifestyle trajectory of individuals ... the quest for a better way of life, itself analogous to the migrants' own self-realization, is a never-ending process (Benson 2011a: 15)

As the quotation above emphasizes, for my interlocutors in the Lot, the pursuit of lifestyle is a prominent feature both of their migration and everyday lives following migration. It is bound up in their identity-making projects; migrant subjectivities are made both through relocation (as an action) and through the choice of a particular destination. Imaginings of rural France are caught up in the reorientations of identity brought about through migration; within lifestyle migration the destination is a site of both social and emotional investments, thoroughly caught up in how a better way of life is imagined. British migration is rural France is an example par excellence of lifestyle migration - the migration of the relatively affluent in search of a better way of life (Benson and 0'Reilly 2009) - as much a description of the process of subjectivity-making as physical movement (Benson 2015; Benson and O’Reilly forthcoming; see also Hoey 2014).

Lifestyle migration as a concept and theoretical framework signals the unique interplay of migration, consumption and identity, accessible to the relatively privileged (Benson and Osbaldiston 2014; Benson and O'Reilly forthcoming). Intended as an inductive concept (Benson and O'Reilly forthcoming), lifestyle migration has been adopted to explain a range of migrations that include wellknown migrant populations such as the British in Spain (O'Reilly 2000, 2012; Kordel 2014); North American migration to Mexico, central and south America (Bantman- 
Accepted for publication in the European Journal of Cultural Studies, forthcoming special issue on Mobile Elites - September 2015

Mausam 2015; Benson 2013a; Hayes 2015); Japanese migration to Australia and to other Asia-Pacific destinations (Hamano 2010; Igareshi 2015; Ono 2014); Northen Europeans to India and the Far East (Korpela 2009; 2010); urban to rural migration within Europe, the United States and Australia (Eimermann 2015; Hoey 2005, 2006, 2014; Osbaldiston 2012); as well as, more recently, the consideration of lifestyle migration to urban locations (Griffiths and Maile 2014; Zaban 2015).

Lifestyle migration is a novel extension of a phenomenon with a history, made possible as a result of global developments of the past 50 or 60 years. It relates specifically to the relative economic privilege of individuals in the developed world, the reflexivity evident in post-/late modernity, the construction of particular places as offering alternative lifestyles, and a more general ease (or freedom) of movement (Benson and 0'Reilly, 2009:620).

As Osbaldiston (2015) argues, at the root of these migrations might be a shared desire for a better way of life, but these are understandably framed by different cultural repertoires that migrants put to work to make sense of migration; lifestyle migration thus emerges as a rather flexible concept, that allows for heterogeneity, rather than being strictly bounded.

Nevertheless, underpinning this is an understanding not only of the migrant as agent, but also of the broad structural and material conditions make lifestyle migration possible, conditions that include globalization, increased mobility and relative economic affluence (Benson and O'Reilly 2009). These contexts frame such migrants' pursuit of a better way of life, often stated alongside a narrative of escape (ibid 2009). However, it remains undeniable that those who can choose to migrate-as with those middle-class subjects who have the choice over where to live (Savage et al. 2005) - have considerable structural and systemic privilege (Benson 2013a). The particularities of such relative privilege rely on context, but almost certainly includes citizenship of globally powerful nation-states-and in the case of intra-european migrations, the freedom of movement for European Union 
(EU) citizens to move between states-a fact that allows them relative ease of mobility. It is also clear that histories of travel and tourism also lay the foundations for this particular migration.

\section{Belonging, the Middle Classes and the Making of Translocal Subjects}

Among my interlocutors in the Lot, privilege was predominantly fractured along lines of class. The accumulation of capitals, assets and resources made possible by their position within the British middle classes (Savage et al. 1992), framed their ability to imagine rural France as offering a better way of life and further, to realize this (Benson 2011). Beyond this, migration is caught up in middle-class reproduction, a way in which these lifestyle migrants seek to distinguish their lives from those of their compatriots (Benson 2011a, 2013b), telling of their sense of belonging. Given the absence of other recognisable markers of middle-class identity-e.g. occupation, employment-residential and housing choices take on enhanced significance for these migrants (see also Butler and Robson 2003; Savage et al. 2005).

The choice to live in the Lot and the value placed upon this locale echoes the concept of elective belonging used elsewhere in the literature on middle-class residential choice (Savage et al. 2005; Benson and Jackson 2013). Under globalisation, belonging may be claimed precisely through the choice to live in a location that has both functional and symbolic importance. Importantly, residential choice is reflexively narrated, demonstrating the relational value of place-why we can live here and why we don't want to live elsewhere-located within individual biographies to demonstrate the fit between the individual and the place of residence (Savage et al. 2005).

It is well-documented that British migration to rural France is inspired by widelyheld cultural imaginings of the destination that circulate among the middle classes (Buller and Hoggart 1994; Barou and Prado 1995; Benson 2011a). These echo Pahl's (1965) 'community in the mind' and the quality of life believed to be offered by 
Accepted for publication in the European Journal of Cultural Studies, forthcoming special issue on Mobile Elites - September 2015

more rural settings; wrought with a cultural logic that valorises social integration, '[T]hey believe that by establishing and maintaining social relations with members of the local French community, they will be able to localise themselves' (Benson 2010: 68). Returning again to the characterisation of my interlocutors as middleclass subjects reveals what might be at stake; belonging to the local community signals that they have been successful in their migration, that they know how to live in rural France. In other words, claims to belonging function within the process of social reproduction (Benson 2011a). Within the destination, these imaginings are put to the test, with lived experience challenging these assumptions of community and locality.

On the one hand, this demonstrates that fit is not easily achieved, not the foregone conclusion that Savage et al. (2005) present. In this way, it overlooks the dynamics and nuances of people's relationships to place(s) (Benson and Jackson 2013), the messy and uncertain process through which belonging is generated and maintained. It becomes clear that the 'fit' between people and place that lies at the root of the concept of elective belonging is something that has to be worked at. Further, within this concept, there is little sense of the social and emotional investments that contribute towards generating belonging. I argue that claiming belonging in a new environment entails emotional investments that have yet to be converted into symbolic capital, the point at which residential choice is legitimated, demosntrating the entanglement of residential mobility in the (re)construction of identities.

On the ether hand, the case of these lifestyle migrants also highlights a misconception at the root of elective belonging, that this is generated in one location: the place of residence. By focussing on these migrants as translocal subjects-'the multiply-located senses of self amongst those who inhabit transnational social fields' (Conradson and McKay 2007: 168) - with lives in one place and multiple links to others (Glick Schiller et al. 1995), allows for the consideration the pull of other locales, and their role in the development of belonging and migrant identities. In this way, the examination presented here calls 
into question the place of residence as the only and perhaps primary site for the generation of belonging among the middle classes. Similarly, the considerable attention on the generation of belonging within the destination-whether with compatriots or the local community (see for example 0'Reilly 2000; Benson 2010, 2011a) - within lifestyle migration research has underplayed the continuation of social relationships between migrants and their relatives and friends in the sending societies (cf. Huber and O'Reilly 2004; Gustafson 2008). This now needs to be redressed within understandings lifestyle migration as a process of subjectivitymaking.

Emotion and affect are one lens onto the developing translocal subjectivities of my interlocutors, revealing the re-orientation of migrant subjectivities (Conradson and McKay 2007; Svašek 2008, 2010). Deeply imbricated in the development of translocal subjectivities, these bring to the fore the complicated relationships that transmigrants have with their particular locales (as opposed to nations) and others living in these locations. In this way a focus on emotion may disclose the ambivalence of migrant subjectivities (Svašek 2010). By refocussing attention onto the emotional negotiations of my interlocutors in the Lot, the ethnography presented in this paper reveals the complexity of lifestyle migrant subjectivities; despite the apparent ease with which these privileged subjects cross borders, the experience of migration and settlement carries is accompanied by ambivalence.

\section{Narrating Migration as Residential Choice}

Lifestyle migration is often described as an individual's search for a better way of life abroad and lifestyle migrants often present themselves as active agents who have improved their lives by way of their own unmediated choice; they have taken their destiny into their own hands by escaping unsatisfactory circumstances and do not expect others (or societies) to act on their behalf. (Korpela 2014: 27; emphasis added) 
Our way into thinking about lifestyle migration has often been the migration narrative; often as a way of breaking the ice, we ask our interlocutors why they decided to migrate and why they selected a particular location. Some studies stop there. Through the presentation of the ethnography in this section, I illustrate how routine responses to the question of why people migrate, in this case to rural France, could contribute to an interpretation of this form of migration as an example par excellence of the ways in which consumption frames globalization (Bauman 1998): lifestyle migrants as typical middle-class consumers who have access to globality as a way of being precisely because they have the freedom to make choices over what they do, in this case, where and how they live (see also Huber and O'Reilly 2004).

In their accounts of the initial decision to migrate, my interlocutors in the Lot focus on the promise that this part of rural France offers the better way of life that they seek comprised of rural community, a more relaxed pace of life, being closer to nature, and safety. These are themes common to the literature on counterurbanization (see for example Pahl 1965; Buller and Hoggart 1994; Halfacree 1994; Boyle and Halfacree 1998) and which circulate and proliferate in popular representations of life in France, such as Peter Mayle's A Year in Provence (1989). They had also drawn their expectations from their prior experiences, often holidays in the area or, in a small number of cases, prior residence. What was clear was that their fond memories coloured their imaginings of the life that was waiting for them there, projecting romanticized images of the French countryside that starkly contrast to their cynical and fatalistic presentations of life in Britain. As has been documented in the case of other British and Western populations abroad (see for example O'Reilly 2000; Oliver 2007), my interlocutors narrate overt dissatisfaction with life back in Britain; this features both a common narrative of the decline of British society and reflections on the personal circumstances of their lives before migration, with an emphasis on a particular watershed event that spurred the act of migration (see also Hoey 2005, 2014). 
Against this background, my interlocutors invariably presented migration as an adventure, claiming themselves as pioneers or trailblazers (Benson 2011: 40; see also Bruillon 2007), part of the wider narrative through which they constructed their migration as distinct. These retrospective narratives carve out migration as a moment of hope and excitement (Fielding 1992), matched by their enthrallment with the surrounding countryside and the views from their country residences. The following representative examples demonstrate the narrative structure that characterizes these migration stories. Following theorists of late/liquid modernity, the performance of these narratives could be argued to reveal the ongoing process through which the self is reflexively (re)constructed (Giddens 1991; Bauman 1995; Sennett 1998).

William and Victoria had both worked as teachers back in Britain, aged in their late thirties they decided to move to the Lot in 2002. From my earliest communications with them, they had stressed that were 'escaping from teaching'. As we sat out in the garden on my first visit to their house in the early spring sunshine, Victoria evocatively described her feelings towards her work as a teacher, 'I felt like I had a life sentence ... I had worked for longer than that!' She had progressed through the ranks and had most recently been the head teacher of a secondary school. Victoria and William had ambitious plans for their lives in the Lot, hoping to run a successful small business from home. They admired the French working culture, which was, in Victoria's opinion 'less rigid' and 'less frenetic', the antithesis of how working life in Britain had been, and imagined themselves working within it in some capacity within the future.

What is particularly notable in Victoria and William's narrative is the resistance to their over-identification as teachers; migration became a way of breaking the dominance of their work within their identities. For others, for whom migration coincided with retirement, the move to France acts as a way of starting over, or reframing identities in the absence of work, taking up the things that in working life they had not had a chance to do, perhaps taking on new challenges. 
For example, Daniel and Alannah had taken early retirement in 2002. They had visited the Lot several times prior to moving to the area, and had been impressed with the life that would be available to them there. As Alannah explained, she had been excited by the idea of living in France, and imagined her daily life filled with the reading and creative writing that she had not had the time to do during her working life.

Choosing to live in the Lot, these migrants engage in a process of elective belonging (Savage et al. 2005). They locate this as the culmination of their biographies, narrating this decision in a way that demonstrates the logic of the fit between themselves and their new environment: what brought them to live there, why they no longer wanted to live in Britain, and what capacities they had that would prepare them for living in France (e.g. speaking French, prior experience of the area). This becomes part of the justificatory framework for their lives in France, with a notable emphasis on belonging.

The Lot features as a place that offers not only a change of scene (although this too is important), but with it a fundamentally different way of living; Hoey's explanation of the migration decision of members of the American middle class migrating to the midwest is particularly pertinent here, 'their decisions about where to live are also about how to live' (2014: 182). Set within a framework focused on consumption (Benson and Osbaldiston 2014), for these privileged subjects, migration is a way of starting over, or reorienting themselves and their lives that are thoroughly moral (ibid 2014) and existential (Osbaldiston 2012), but which are fundamentally about individual subjects and the ability to remake themselves (see also Hoey 2005, 2006). We could end the story there, with the indisputable privilege of lifestyle migrants to seek and consume landscapes that represent 'the good life', migration presented as a self-chosen form of self-realization. However, refocussing attention on lived experience and in particular the affective and emotional registers of these demonstrates that these migrants have a more uneasy relationship with their surroundings. Further complicated by the continued pull of relationships to other 
Accepted for publication in the European Journal of Cultural Studies, forthcoming special issue on Mobile Elites - September 2015

locales, focussing on emotion thus allows for deeper insights that reveal further how translocal subjectivities are (re)made in and through migration and settlement.

\section{Emotions and Lifestyle Migrant Subjectivities}

While narratives that recall the decision to migrate are either dispassionate, presented as rational, or accompanied by positive emotions of excitement, the development of greater rapport with my interlocutors brought the emotional negotiations inherent to processes of migration and settlement to the surface. It is undeniable, that even for these privileged subjects, migration is emotionally moving (Conradson and Mackay 2007; Svašek 2008; Jones, Jackson and Rhys-Taylor 2014), with the capacity to reinvigorate connection and attachment (Ahmed 2004; Gray 2008). And yet, as Bude and Dürrschmidt (2010) argue, the emotions that accompany migration are often overlooked in díscussions of privileged migration (cf. Walsh 2010).

\section{(Un)Settling Emotions}

I sat up in bed the first morning after we arrived here and said, "I'm putting it [the house] on the market immediately; I'm not staying here"... I didn't realize that when he [husband] wasn't here, I was going to be completely isolated. The nearest, lively, village is $5 \mathrm{~km}$ from here, so there is no way I can push my trolley $5 \mathrm{~km}$ there and $5 \mathrm{~km}$ back to do the shopping. So, I need somebody to do my shopping and, because I wasn't well, I needed somebody to do the housework.-Deborah, aged 75

Deborah and Hector had bought a large, two-storey house in a small hamlet on the causse (limestone plateau). Its elevated position meant that it had a beautiful view over the hills and farmland that surrounded it, but it was some distance away from the nearest village and any amenities. Hector was still working, and spent long periods of time abroad, while Deborah lived in the Lot full-time. This seemed to have been a substantial oversight on their part; Deborah suffered from a chronic 
Accepted for publication in the European Journal of Cultural Studies, forthcoming special issue on Mobile Elites - September 2015

condition and could not drive and so, when Hector was away, she found herself housebound and isolated. The isolation of the house was synonymous to the loneliness that Deborah felt, a stark contrast to the vitality and busy-ness of her working life as a publicist and agent within the film industry, which had seen her travelling all over the world.

It was through William and Victoria that I came to know Deborah; she had first contacted William to come and fix her computer, and later invited him, Victoria and their dogs around for a lunch. With my permission, William and Victoria had passed on my details to Deborah one afternoon when I was visiting them; by the time I reached home two or three hours later, Deborah had already called, keen that I go to visit. From then on, I regularly visited Deborah, brought her supplies when she needed them, and took her on outings to the local town It was often difficult to leave her company; she would find ways to delay you, Lassume so that she would not be left alone. In between my visits she often called, to the extent that the family I was staying with made jokes and comments about it. It was clear that she sought and needed company in a way that she had failed to anticipate when they had bought their house on the hill. When I returned to the Lot in 2005, Deborah had moved to a house in the centre of a local town. She could now buy food locally, there was a restaurant a hundred metres from the front door, and there was even an English bookshop. She was much more settled and happy than she had been previously, and had even made some friends-both French and English—locally.

As the opening quotation to this section demonstrates, the experience of moving and settlement had been deeply emotional and visceral. Admittedly, in Deborah's case there were very real physical and geographical constraints that may have shaped experience in this way, but it also became clear that for several of my interlocutors the experience of settlement was not straightforward. Framed by their imaginings of post-migration life, disappointment and frustration with the everyday realities of their lives in France was not uncommon. Given how migration intersects 
Accepted for publication in the European Journal of Cultural Studies, forthcoming special issue on Mobile Elites - September 2015

with self-fulfillment and subjectivity, these emotional reactions should not be taken lightly.

One way in which this was articulated was through an account of their inability to settle into the local community, by which they meant making friends with some of the local French. Alannah had described to me how her original hopes for life in France had included having a close circle of French friends; she had imagined roaming the local woodland with them, romantically anticipating that through them she would develop an indigenous, local knowledge. While it is clear that these imaginings were flawed on many grounds-not least the way that the local population is exoticized and rendered authentic, in this way presented as the Other and therefore perhaps more revealing of the reproduction of Englishness following migration than of becoming local (Aldridge 1995) - it is also apparent that the failure to meet these was a considerable source of disappointment, turned in on the self. Indeed, Alannah explained, 'my only real regret is not having French friends'; despite speaking fluent French and reaching out to her neighbours and others living in the local village, she felt her efforts had met with little success. In contrast to this general sense of disappointment, she recalled with excitement her small triumphs, invitations from the local French to attend their events and celebrations; in these moments, she was filled with pride, stressing what a sense of achievement this represented for her.

For Hannah, an elderly woman who had moved to the Lot alone in the early 1990s, this sense of disppointment was even more marked. She had learned to speak fluent French in anticipation of her relocation, and had chosen to live in a village where she was the only English person; she had imagined that these actions would help her to become friends with local people. In the absence of the possibility of building up working relationships, she thought that one way to meet some local people might be to offer English lessons. Nearly fifteen years later, she still had very few French friends; her neighbours were out at work all day and they already had many friends and family in the village. She painted a particularly poignant picture, expressing how she felt lonely in her village, where even after fifteen years, her neighbours did no 
more than pass the time of day. While Hannah knew many of the British living locally, she did not feel as though she fit in with them either. Her account conveyed the sense that she could not find a place to belong. Explaining this in a deliberately measured tone, marked these 'facts' of her daily life as emotional, the occasional quiver and hestitation further betraying this.

Hannah and Alannah's reflections on their efforts to re-embed themselves, seeking out explicitly local social relations are representative of the way that many of my interlocutors articulated their lives in the Lot; the desire for (and achievement of) local relationships was incorporated into their identity claims. The performance of emotion and the embodied dimensions of how these desires were conveyed demonstrates that this is more than rhetoric; it is profoundly linked to how they imagined life both life in rural France and how they had reconfigured their ideas about belonging. Vivian, another of my interlocutors who had successfully developed friendships with local French women, while expressing the same emotions of sadness and disappointment, described how she had hoped that alongside their French friends, she would also have had close British friends in the Lot. This demonstrates the complexities of how belonging is conceived, cutting across categories of local and global, French and British.

\section{Emotional ties}

The other side of the coin, however, are the emotions relating to leaving friends and family in Britain. Hannah had an adult son who had Down's syndrome. He lived back in Britain in sheltered accommodation and Hannah took regular trips to visit him. She knew that she could not bring him to France; her earlier investigations had revealed that there was no equivalent sheltered accommodation and work schemes to those that he was used to in Britain. Although it was evident that the services and support he received in Britain could not be matched in France, it made her anxious and sad that she could not see him more regularly. As she described this, her eyes welled up with tears, her narrative punctuated with hesitations as she swallowed by the emotions that this had brought to the surface. As she battled through these 
Accepted for publication in the European Journal of Cultural Studies, forthcoming special issue on Mobile Elites - September 2015

conflicting pragmatic and emotional concerns, she revealed further her disappointment in her life in France and demonstrated some of the difficulties of transnational family life (cf. Baldasser 2008; Ryan 2008).

Ann had experienced similar dilemmas. She spoke earnestly about the relationship that she had with her mother. Soon after Ann had moved to the Lot, her elderly mother had been taken ill. Ann felt that she was under a lot of pressure from her mother and from the medical profession to return to Britain as her mother's carer. Ann described the rather fraught relationship that she had always had with her mother. She explained that ultimately she had decided not to go back; although it had been an easy decision to take, she had decided to let the medical profession look after her mother. She said that there was a time when the hospital was ringing her every day to tell her that her mother had fallen out of bed. She didn't know what exactly she was supposed to do about it from the Lot, and had started to dread answering the phone. Describing this, her voice became more shrill and her face visibly red, the anger that she felt at haying been put in this position coming once again to the surface in the process of recollection.

Concerns for children and elderly relatives back in Britain were common to the accounts of migrants, a dimension of their lives that illustrated the emotional and spatial negotiations that characterized their daily lives. While they often travelled to look after relatives in need-those who were ill and elderly, or who had had operations and were in recovery - many of my interlocutors would take 'holidays' to Britain precisely to visit friends and family, the frequency and timing of such visits relying on what funds were available and what commitments they had in France. In addition to physical travel, they also maintained regular communication via phone.

\section{Conclusion}

For my interlocutors in rural France, the migration and settlement experience is moving, accompanied by a range of emotional responses. Lifestyle migration is both exciting and challenging, a chance to start over in a new location. The emotional 
registers through which migration and settlement are experienced highlight that even for these relatively privileged migrants the experience of migration and settlement is characterized not by a smooth flow that aligns with the ease with which they can cross borders. It is rather a rougher and perhaps more turbulent encounter as indicated by the unsettling capacity of finding home and belonging. Moving between localities these migrants feel the absence and pull of social relations, struggling to establish social relations on the ground within the destination and maintain those with friends and family back in Britain. Lifestyle migrants make social and emotional investments in the destination, a site that is often highly localised, but this does not negate the possibility of maintaining such investments elsewhere.

The focus on emotions and lived experience presented here unsettles the concept of elective belonging (Savage et al. 2005). It makes clear that belonging is neither fait accompli nor rooted in one location. While choice plays a significant role within the decision to migrate-a form of residential choice-and migrants narrate this choice to highlight how it fits to their biographies and how they they are at home in the places selected, as the ethnographic narratives presented here have shown, these are just the headlines to a much more complicated story of belonging and classed identity formation.

\section{List of references}

Ahmed, S. (2004) 'Collective Feelings or, The Impressions Left by Others', Theory, Culture and Society 21(2): 25-42.

Aldridge, A. (1995) The English as they see others: England revealed in Provence, The Sociological Review 43(3): 415-434. 
Accepted for publication in the European Journal of Cultural Studies, forthcoming special issue on Mobile Elites - September 2015

Baldassar, L. (2008) 'Missing Kin and Longing to be Together: Emotions and the Construction of Co-presence in Transnational Relationships', Journal of Intercultural Studies 29(3): 247-66.

Bantman-Masum, E. (2015) 'Lifestyle Transmigration: Understanding a Hypermobile Minority in Mérida, Mexico', Journal of Latin American Geography 14(1): 101-118.

Bauman, Z. (1998) Globalization: The Human Consequences. Cambridge: Polity Press.

Bauman, Z. (1995) Life in Fragments: Essays in Postmodern Morality. Oxford: Blackwell.

Benson, M. (2013a) 'Postcoloniality and privilege in newlifestyle flows: the case of North Americans in Panama', Mobilities 8(3): 313-330.

Benson, M. (2015) 'Lifestyle Migration: From the State of the Art to the Future of the Field', Two Homelands 42: 9-23.

Benson, M. and Jackson, E. (2013) 'Place-making and place maintenance: Practices of place and belonging among the middle classes', Sociology 47(4): 793-809.

Benson, M. and Osbaldiston, $\mathrm{N}$ ( 2014) 'New horizons in lifestyle migration research: theorizing movement, settlement and the search for a better way of life', in M. Benson and N. Osbaldiston(eds) Understanding lifestyle migration, pp. 1-25. London: Palgrave

Benson, M.\& O'Reilly, K. (2009) 'Migration And The Search For A Better Way Of Life: A Critical Exploration Of Lifestyle Migration', The Sociological Review 57(4): 608-25. Benson, M. \& O’Reilly, K. (forthcoming) 'From Lifestyle Migration to Lifestyle in Migration: Categories, concepts and ways of thinking', Migration Studies.

Boyle, P., and Halfacree, K. (1998) 'Migration, Rurality and the Post-Productivist Countryside'. In P. Boyle and K. Halfacree (eds) Migration into Rural Areas: theories and issues, pp. 1-20. Chichester: John Wiley and Sons Ltd. 
Accepted for publication in the European Journal of Cultural Studies, forthcoming special issue on Mobile Elites - September 2015

Bruillon, M. (2007) 'A Peculiarly British Sense of Adventure? The Discourse of Emigrants', in C. Geoffrey and R. Sibley (eds) Going Abroad: Travel, Tourism and Migration, pp. 132-143. Cambridge: Cambridge Scholars Publishing.

Bude, H. and Dürrschmidt, J. (2010) 'What's wrong with globalization?: Contra 'flow speak' - towards an existential turn in the theory of globalization', European Journal of Social Theory 13(4): 481-500.

Buller, H. and Hoggart, K. (1994) International counterurbanization. Aldershot: Avebury.

Butler, T., Robson, G. (2003) London Calling: The Middle Classes and the Re-making of Inner City London. Oxford: Berg.

Conradson, D. and Mackay, D. (2007) 'Translocal Subjectivities: Mobility, Connection, Emotion', Mobilities 2(2): 167-174.

Eimermann, M. (2015) 'Lifestyle Migration to the North: Dutch Families and the Decision to Move to Rural Sweden', Population, Space and Place 21(1): 68-85.

Fielding, T. (1992) 'Migration and Culture', in A. Champion \& T. Fielding (eds) Migration Processes and Patterns: Research Progress and Prospects, pp. 201-214. London: Belhaven Press.

Giddens, A. (1991) Modernity and Self-Identity: Self and Society in the Late Modern Age. Cambridge: Polity Press.

Glick Schiller, N., Basch, L., and Szanton Blanc, C. (1995) 'From Immigrant to Transmigrant: Theorizing Transnational Migration', Anthropological Quarterly 68(1): 48-63.

Gray, B. (2008) 'Putting Emotion and Reflexivity to Work in Researching Migration', Sociology 42(5): 935-52.

Griffiths, D. and Maile, S. (2014) 'Britons in Berlin: Imagined Cityscapes, Affective Encounters and the Cultivation of the Self', in M. Benson and N. Osbaldiston, (eds) Understanding Lifestyle Migration: Theoretical Approaches to Migration and the Quest for a Better Way of Life, pp. 139-162. Basingstoke: Palgrave Macmillan. 
Accepted for publication in the European Journal of Cultural Studies, forthcoming special issue on Mobile Elites - September 2015

Gustafson, P. (2008) 'Transnationalism in Retirement Migration: The Case of North European Retirees in Spain', Ethnic and Racial Studies 31(3): 451-475.

Halfacree, K. (1994) 'The importance of 'the rural' in the constitution of counterurbanization: Evidence from England in the 1980s', Sociologia Ruralis 34(23): 164-189.

Hamano, T. (2010) Searching Better Lifestyle in Migration: The Case of Contemporary Japanese Migrants in Australia, Germany: LAP Lambert.

Hayes, M. (2015) 'Into the Universe of the Hacienda: lifestyle migration, individualism and social dislocation in Vilcabamba, Ecuador', Journal of Latin American Geography 14(1): 79-100.

Hoey, B. (2005) 'From Pi to Pie: Moral Narratives of Noneconomic Migration and Starting Over in the Postindustrial Midwest', Journal of Contemporary Ethnography 34(5): 586-624.

Hoey, B. (2006) 'Grey Suit or Brown Carhartt: Narrative Transition, Relocation and Reorientation in the Lives of Corporate Refugees', Journal of Anthropological Research 62(3): 347-371.

Hoey, B., (2014) Opting for Elsewhere: Lifestyle Migration in the American Middle Class, Nashville: Vanderbilt University Press.

Huber, A. and O'Reilly, K. (2004) 'The Construction of Heimat under Conditions of Individualized Modernity: Swiss and British Elderly Migrants in Spain', Ageing and Society $24(3): 327-351$.

Igarashi, H. (2015) 'Privileged Japanese Transnational Families in Hawaii as Lifestyle Migrants', Global Networks 15(1):99-117.

Jones, H., Jackson, E., and Rhys-Taylor, A. (2014) 'Introduction: Moving and Being Moved', in H. Jones and E. Jackson (eds) Stories of Cosmopolitan Belonging: Emotion and Location, pp. 1-14. London: Routledge.

Kordel, S. (2014) 'The production of spaces of the good life - the case of lifestyle migrants in Spain', Leisure Studies [published online 29 Sep 2014]. 
Accepted for publication in the European Journal of Cultural Studies, forthcoming special issue on Mobile Elites - September 2015

Korpela, M. (2009) More Vibes in India. Tampere: University of Tampere Press.

Korpela, M. (2010) 'A Postcolonial Imagination? Westerners Searching for Authenticity in India', Journal of Ethnic and Migration Studies 36(6): 1299-1315.

Korpela, M. (2014) 'Lifestyle of Freedom? Individualism and Lifestyle Migration', in M. Benson and N. Osbalidston (eds) Understanding lifestyle migration, pp. 27-46. Basingstoke: Palgrave MacMillan.

Mayle, P. (1989) A Year in Provence. London: Pan Books.

O'Reilly, K. (2000) The British on the Costa del Sol : transnational identities and local communities. London: Routledge.

O’Reilly, K. (2012) International Migration and Social Theory. Basingstoke: Palgrave.

Oliver, C. (2007) Retirement migration : paradoxes of ageing. New York ; London: Routledge.

Ono, M. (2014) Commoditization of Lifestyle Migration: Japanese Retirees in Malaysia, Mobilities [published online].

Osbaldiston, N. (2012) Seeking Authenticity in Place, Culture and Self: The Great Urban Escape. New York: Palgrave Macmillan.

Osbaldiston, N. (2015) 'A Cultural Sociology Reading of Lifestyle Migration', Two Homelands 42: 25-36.

Pahl, R. (1965) 'Class and Community in English Commuter Villages'. Sociologia Ruralis: journal of the European Society for Rural Sociology 1: 5-23.

Ryan, L. (2008) 'Navigating the Emotional Terrain of Families "Here" and "There": Women, Migration and the Management of Emotions', Journal of Intercultural Studies 29: 299-313.

Savage, M., Barlow, J., Dickens, P., and Fielding, T. (1992) Property, Bureaucracy and Culture: Middle-class Formation in Contemporary Britain. London: Routledge.

Savage, M., Bagnall, G., Longhurst, B. (2005) Globalization and Belonging. London: SAGE. 
Accepted for publication in the European Journal of Cultural Studies, forthcoming special issue on Mobile Elites - September 2015

Sennett, R. (1998) The corrosion of character: the personal consequences of work in the new capitalism. New York: W.W.Norton.

Skrbis, Z. (2008) 'Transnational Families: Theorising Migration, Emotions and Belonging', Journal of Intercultural Studies 29: 231-246.

Svašek, M. (2008) 'Who Cares? Families and Feelings in Movement', Journal of Intercultural Studies 29(3): 213-230.

Svašek, M. (2010) On the Move: Emotions and Human Mobility, Journal of Ethnic and Migration Studies 36(6): 865-80.

Wagner, L. (forthcoming) 'Viscosities and Meshworks', in K. Hartmann-Petersen, E. Perez Fjalland and M. Freudandel-Pedersen (forthcoming) Networked Urban Mobilities Volume 2: Experiencing.

Walsh, K. (2012) 'Emotion and Migration: British Transnationals in Dubai', Environment and Planning D: Society and Space 30(1): 43-59.

Zaban, H. (2015) 'The Effects of Lifestyle Migration of Jews from Western Countries on Jerusalem', Two Homelands 42: 53-67.

Benson, M. (2010) 'We're not Expats; we are not Migrants; we are Sauliaçoise': Laying Claim to Belonging in Rural France', in B. Bonisch-Brednich and C. Trundle, (eds) Local Lives: Migration and the Micro-politics of Place, pp. 67-84. Farnham: Ashgate.

Benson, M. (2011a) The British in Rural France: Lifestyle Migration and the Ongoing Quest for a Better Way of Life, Manchester: Manchester University Press.

Benson, M. (2011b) 'The movement beyond (lifestyle) migration: mobile practices and the constitution of a better way of life', Mobilities 6 (2): 221-235.

Benson, M. (2013b) 'Living the 'Real' Dream in La France Profonde: Lifestyle Migration, Social Distinction, and the Authenticities of Everyday Life', Anthropological Quarterly 86(2): 501-525. 